\title{
Employee Engagement, Voice Mechanisms and Enterprise Social Network Sites (ESNS)
}

\author{
Pamela Estell \\ Communications and Information Sciences \\ University of Hawai'i Mānoa \\ pestell@hawaii.edu
}

\author{
Elizabeth Davidson \\ Shidler College of Business \\ University of Hawai'i Mānoa \\ edavidso@hawaii.edu
}

\begin{abstract}
Effective organizational communication allowing a two-way flow of communication between subordinates and upper management can foster greater levels of engagement and productivity. This is often referred to as providing opportunities for direct employee "voice." Understanding the influence and impact of ICTs on employee voice and engagement are critical for the success of modern organizations. ICTs can enhance the reach, speed, and interaction among employees, and between employees and management. Observing the success of social technologies for personal use, employers have been eager to capitalize on social technologies to engage employees by implementing enterprise social network sites (ESNS). Whether ESNS will be an effective tool in enhancing voice and engagement, and what potential drawbacks exist for employees and firms have yet to be fully studied. This article presents a review of the literature on the intersection of employee voice, engagement, and ICTs, and suggests a research framework to guide study of ESNS for organizational employee voice.
\end{abstract}

\section{Introduction}

Employee engagement has been broadly defined as an employee's physical, cognitive, and/or emotional connection to their organization [29]. Management scholars have studied employee engagement through a variety of lenses - organizational communication being one that has received particular attention due to its broad application. Internal [organizational] communication has traditionally referred to the organizational practices of distributing key corporate messages through newsletters, emails, intranet sites, direct messaging applications, meetings, conversations, or videos [63]. As organizations have grown and become more dynamic, attention has begun to shift toward a two-way flow of communication and relationship building between organizations and their employees [56], [31]. The idea of leveraging intraorganizational communication networks to encourage employee prosocial (helpful) voice has been investigated by researchers attempting to draw correlations between direct voice practices [32], engagement, and organizational success.

Hirschman [23] initially conceptualized employee voice as individually or collectively seeking a change in an objectionable state through the use of voice practices. Since then, research into the use of voice has been studied within the Human Resource Management, Employee Relations, and Organizational Behavior fields [48], and more recently, in the Public Relations literature [59]. Studies have shown a marked correlation between employee voice and greater levels of employee engagement [26], which can ultimately have an impact on overall organizational productivity [32] and a decrease in turnover [8]. Prioritizing direct voice will continue to be a critical effort in contemporary firms, especially in an era where immediate and widely accessible information and communication technologies (ICTs) proffer myriad opportunities for employees to express themselves.

As employee engagement, voice, and ICTs collide in modern workspaces on a daily basis, understanding their interaction is a crucial step in proactively and productively managing organizational communication dynamics. The potential for valuable organizational outcomes is great, as are the risks of public relations and organizational disruptions from inappropriate or unexpected uses of ICTs for employee voice $[30,36$, $37,62,64,70]$. Further study of the potential for ICTs, and particularly newly emerging communication channels enabled by social media to influence the methods for, use of, and outcomes of voice is merited [49]. This paper contributes to the literature on employee voice through consideration of the impacts of ICTs, specifically enterprise social network sites (ESNS), on voice and engagement and a proposed research framework and agenda.

\section{Theoretical Foundations}

The following review highlights key literature on employee engagement and voice as a foundation for considering the implications of ENSNs. 


\subsection{Employee Engagement and Voice}

Researchers have long studied employee engagement as a metric that influences overall organizational success on various dimensions. Studies have supported early notions of employee voice, finding that employees who are more engaged on all three psychological levels (cognitive, behavioral, and emotional) tend to be more engaged in, and committed to, an organization [59]. Researchers have also addressed engagement from the lens of rewards versus relationships, arguing that the answer to engaging employees lies in energizing relationships that influence and promote continued engagement and positive feelings towards peers and management [12]. Still others have posited that content, specifically individual employee expectations of content, such as job security or employee voice can lead employees to higher levels of organizational identification and engagement [58]. Empirical research has confirmed that internal organizational communication and internal supervisor communication support workplace relationships based on meaning and worth and have a significant part to play in developing and maintaining optimal employee engagement [31].

Employee engagement and voice can be addressed as a multidimensional construct, which can be leveraged by organizations to foster greater corporate engagement. In the HR field, Rees, Alfes, \& Gatenby [56] found in an empirical organizational study of the UK service sector, that positive relationships existed between voice and engagement, voice and trust in senior management, trust in senior management and engagement, and the employee-line manager relationship and engagement.

From a Public Relations prevue, researchers have studied associations between upward employee voice, senior manager receptiveness to voice, and employee engagement to highlight two aspects: upward communication from employees, and senior management receptiveness to employee voice [59]. Findings indicate a significant and positive relationship between upward employee voice and emotional organizational engagement as well as positive relationships between senior manager receptiveness and emotional organizational engagement.

To summarize, such research points to communication dynamics that include employee voice and interrelationships with organizational participation and engagement and highlights voice as a valuable area for internal communication scholarship [48, 49, 59].

\subsection{Employee Voice}

Although his early exposition focused on customers, not employees, Hirschman [23] was arguably one of the first scholars to investigate and conceptualize the idea of voice, specifically as:

"any attempt at all to change, rather than to escape from, an objectionable state of affairs, whether through individual or collective petition to the management directly in charge, through appeal to a higher authority with the intention of forcing a change in management, or through various types of actions or protests, including those that are meant to mobilize public opinion." (p. 30)

Since then, his Exit-Voice-Loyalty theory has been applied more broadly to employees, leading researchers to investigate employee voice in a variety of disciplines. Many components within the voice literature have been studied previously-including power, trust, and silence [48].

Voice may be exercised through formal mechanisms, such as a grievance procedure, or though informal communication channels, such as one-on-one meetings. A key differentiation has also been drawn between direct and indirect voice. Direct employee voice within organizations, which is "voice uninhibited by formal hierarchical structures, giving way to direct lines of communication between management and individual employees" [24, p. 140]. Traditionally, direct voicing has included activities such as one-toone meetings with managers or team briefings by managers to employees (to name a few). Indirect voice has historically been provided via trade union representatives. However, declining union density, particularly in the UK and US, has eroded workplace labor organization. Lewin [38] draws out the evolution of employee voice from a system largely dependent on unionized and indirect forms of grievance management to direct non-unionized alternative dispute resolutions. He points out that even with a plethora of formal procedures with which to air grievances, informal options are much more common and take place largely via informal channels.

Thus, voice is increasingly viewed through the lens of employee engagement [72] as direct employee voicing via informal channels. This focus then directs research on motivations for voicing, the relationship between voice and engagement, and the choice of voice mechanisms, which are relevant to understanding the roles of ICTs generally, and ESNS in particular.

\subsection{Motivations for Employee Voicing}

Lewin [38] highlights grievance as reason to voice. This builds on the idea of 'principled organizational dissent' [20] where attention is drawn to efforts of employees to protest and/or change the organizational status quo. Lewin [38] takes this idea a step further by pointing to the mechanisms individuals use to engage 
in protest. Dissenting, or, sounding the alarm on concerns of ethic or the general status quo, complements research on whistleblowing, that is, using voice to disclose perceived wrongdoing so that management can take action [50].

While it is true that expressing grievances and dissent have an important role in overall organizational well-being, these are not the only reasons employees choose to exercise voice. Many research streams point to employees' use of prosocial voice as a means to go above and beyond job duties to the benefit of the organization, even pointing to the use of voice as a way in which employees engage with their firms. In much of the organizational behavior literature, voice is seen as a prosocial practice that is other-oriented and focused on the organization. For instance, Van Dyne \& LePine [69] found via a six-month longitudinal study, that voice is perceived as an extra role behavior, being both positive and discretionary. The authors define voice as a proactive, promotive, and challenging functional behavior that emphasizes expression of constructive challenges intended to improve rather than merely criticize [69]. Voice as a prosocial tool has also been found to aid in constructive and proactive behaviors like voicing high standards, challenging others, or making suggestions for change [68]. Furthermore, scholars have recognized that voice can be used to contribute to management decision-making, in which employees seek improvements in work organization, quality, and productivity as well as to achieve long-term viability for both organizations and employees [16].

\subsection{Future Voicing Research Directions}

Given the breadth, volume and variety of voice components within the overlapping, yet distinct literatures noted above, Mowbray, Wilkinson, \& Tse [48] address ways in which a common conceptualization of employee voice may be reached in order to identify new theories on employee voice and its practical implications for organizations. Their research concluded that fragmentation within disciplines (Human Resource Management/ Employee Relations, and Organizational Behavior) have resulted in a large body of research on organizational voice that lacks an overarching theory explaining how to operationalize the voice construct. Table 1 summarizes key points raised by their review as well as other reviews $[3,46]$. While they did not consider research from fields like organizational psychology or organizational communication, Mowbray, Wilkinson, \& Tse [48] acknowledge that studies within these respective literatures could provide additional and valuable contributions in understanding reasons for voicing and its effect on choice of voice mechanism.

\begin{tabular}{|l|l|l|}
\hline Discipline & Voice Attributes \& Motivations & Limitations \\
\hline Human Resource & - Grievance procedures [48] & - Focuses too heavily on the \\
Management/ & - Participation in decision-making [48] & component of voice that is \\
Employee & - Challenging status quo [46] & - Focuses on a collective. [3] \\
Relations & - Prohibitive or promotive \\
(HRM/ER) & - Dissatisfaction [48] & \\
& - Prosocial [48] & \\
\hline $\begin{array}{l}\text { Organizational } \\
\text { Behavior (OB) }\end{array}$ & $\begin{array}{l}\text { - Communicating different points of } \\
\text { view [48] }\end{array}$ & $\begin{array}{l}\text { - Focuses too heavily on } \\
\text { voice as prosocial and }\end{array}$ \\
& $\begin{array}{l}\text { - Improving organizational or unit } \\
\text { functioning. [48] }\end{array}$ & $\begin{array}{l}\text { neglects voice as } \\
\text {-complaining'. [3] }\end{array}$ \\
& - Challenging status quo. [46] & - Focuses on individual, \\
& - Altruistic [46] & communicative aspects of \\
& - Prosocial [48] & voice. [3] \\
& - Justice [48] & \\
\hline & - Dissatisfaction [48] & \\
\hline Adapted from Mowbray, Wilkinson, \& Tse [48], Mayes \& Podsakoff [46], \& Barry \& Wilkinson [3]
\end{tabular}

Table 1: Overview of Voicing Literature

Taking this body of literature into account, we focus our research interest in the intersection of employee engagement, voice and ESNSs on direct voicing behaviors in informal channels, motivations for voicing, and communication mechanisms to facilitate such voicing behaviors. Consistent with Hirschman's [23] theory, and following Holland [24], we define employee voice as the two-way communication process between employers and employees that

"...takes the frame of reference from just raising concerns and expressing and advancing interests, to facilitating employee engagement, contribution and commitment to participating in workplace decisionmaking and solving problems to achieve organizational goals" [24, p. 139].

We turn now to the literature on ICTs in organizational communication, which can inform our research framework for employee voicing and ESNSs.

\section{ICTs and Employee Voice}

Information and Communication Technologies (ICTs) have played a significant role in internal organizational communication processes by breaking down barriers of time and space, as well as barriers related to social and organizational boundaries [51]. The complex relationship between technology and communication has been studied for decades, with early theories, such as Media Richness, suggesting that the primary goal of organizational participants is to reduce ambiguity through media selection [13]. Email, one of the earliest forms of social technologies having 'one-to-many' features, changed the nature of internal and external organizational communication by enabling the "instant transfer of messages and documents worldwide" [61, p. 35]. As researchers spent many early years dissecting the ripple effects of email within corporate life, they found that the benefits of email use such as access to superiors, status equalization, and volume of new information shared $(60 \%)$, outweighed 
issues of weak social cues, irresponsible behavior, and overestimations of personal contributions [64].

As ICTs have evolved, their features continue to be leveraged to meet personal and organizational needs. Licoppe \& Smoreda [40] found that ICTs such as answering services, email, and text messages may act as a surrogate for co-presence when face-to-face communication is not possible or difficult to organize. They found the emergence and reinforcement of new social patterns where "presence" was no longer simply the opposite of absence, as individuals took advantage of the low-cost features of ICTs in their communication practices, which in turn altered user perceptions of the construct of "presence" itself and an always on, "connected presence" [39].

Beyond investigations on particular types of ICTs and their implications for organizational communication, the roles of ICTs for organizational knowledge management has been extensively studied [see 1, 19, 28, 44, 55, 60, 67]. Sharing knowledge can be viewed as a use of prosocial voice within organizations due to its focus on accomplishing organizational goals. It has also been argued to be a fundamentally communicative function due to its reliance on the transfer of knowledge via communities of practice [5]. The relationship between knowledge management and voicing behaviors per se has received less explicit attention in the literature.

\section{From ICTs to Social Media to ESNS}

Emerging ICTs such as Facebook, Twitter, Wikipedia, and other social platforms have changed the reach, immediacy, and flow of communication both personally and professionally. Definitions of social media and social networking sites vary. Carr \& Hayes's [9] broad conceptualization of social media suggests they are "Internet-based, disnentrained and persistent channels of masspersonal communication facilitating perceptions of interactions among users, deriving value primarily from user generated content" (p.49). boyd \& Ellison's [6] definition of social networking sites indicates networked communication platforms where participants have identifiable profiles with user (and other) supplied content, and/or systemprovided data; publicly articulated connections traversable by others; and, participants who consume, produce, and/or interact with user-generated content provided by their connections. Among other reasons, researchers have concluded that individuals engage in social media use to connect with people in their communities [5], for social support [54], as well as enjoyment, utility, and the opportunity for greater network externalities [41].
While ICTs like social networking sites for personal use have become more ubiquitous, using these same technologies to facilitate the flow of organizational communication (and hence, productivity) has gained more attention in recent years $[15,17,34]$. Ellison et al. [17] define enterprise social networking sites, or ESNS, as a form of SNS used within organizations that are formally sanctioned by management, allow for collective affordances, and have the ability to restrict membership or specific interactions to members of a specific enterprise. Managers have begun to perceive the value of collaborative technologies for achieving goals, positing that if individuals regularly communicate and collaborate using dynamic technology in their personal lives, these same tools can be implemented in organizations to support the flow and exchange of communication and knowledge. Spurred by developments in the ESNS marketplace, organizations are now adopting ESNS such as Beehive [15], Yammer, Jive, and Socialcast [42] (among others) in an attempt to capitalize on their benefits for organizing $[15,34]$, albeit with varied results.

\subsection{ESNS and Communication Affordances}

Leonardi and Vaast [34] conceptualize an affordance perspective for organizing, noting that "an 'affordance' refers to the potential for action that new technologies provide to users" (p. 7). They go on to assert that technologies embody material features with properties that go beyond their context of use, and "when individuals perceive that those features allow them to perform certain actions, the technology can be said to provide an 'affordance"' (p. 7).

Key affordances of ESNSs for knowledge sharing and general communication include visibility $[18,66]$, association of content and people, persistence, editability [66], and finding common ground with latent or weak ties $[17,21]$. Leonardi et al. (37, p.2) posit more specifically that enterprise social media allow workers to (1) communicate messages with specific coworkers or broadcast messages to everyone in the organization; (2) explicitly indicate or implicitly reveal particular coworkers as communication partners; (3) post, edit, and sort text and files linked to themselves or others; and (4) view the messages, connections, text, and files communicated, posted, edited, and sorted by anyone else in the organization at any time of their choosing.

Other scholars have noted affordances such as "communicational ambidexterity," which provides "the capability to simultaneously address different and often conflicting communication needs that exist in an organization's internal communication" (p. 50) [27]. 
In addition, due to its affordances of personalization [15], ESNS can be used as an outlet for individual expression, which may lead to higher levels of overall employee engagement and job satisfaction [25].

Much like Erickson [18] points out in his exposition of how digital systems can support social intelligence via shared visualization, ESNS may provide employees with the opportunity to visualize information, connections, and content within a system, which may reinforce organizational social norms. Leonardi [35] focuses on this visibility in what he terms ambient awareness, or a peripheral awareness of conversations and messages happening across an organization that require little cognitive energy to process and can be revisited at a later time.

Majchrzak, Faraj, Kane, \& Azad [43] highlight the affordance of metavoicing as "engaging in the ongoing knowledge conversation by reacting online to others' presence, profiles, content and activities," (p.41). Metavoicing, then, is not simply voicing an individual opinion, but adding metaknowledge to content already online. Metavoicing can take many forms including retweets, votes on postings, commenting on someone's post, and "liking," among others. As such, when decisions need to be made in the workplace, the sentiment of the workforce (made possible via metavoicing) can be helpful in creating a conversation that incorporates more opinions than would otherwise be possible [43].

\subsection{ESNS as a Mechanism for Voicing}

The affordances of enterprise social technologies allow for collaboration and communication in ways that have not been possible before. Some of these uses may be related to voicing. However, while research on leveraging ESNS broadly for knowledge sharing purposes is growing $[17,30,33,34,35,36,43,71]$ far less investigation has yet been directed towards affordances of ESNS as a mechanism for employee voice (although researchers have noted its potential) $[26,34,44]$. ESNS uses for direct voicing may diverge from earlier forms of social software such as email, blogs, or wikis, whose connections were more ambiguous, more tightly controlled by individuals within an organization, and were typically only shared with select viewers the originator intentionally identified. As a result of its ability to span communication boundaries, ESNS have the potential to change the undergirding power dynamics within organizations that have traditionally relied on a chainof-command reporting structure [64] and thus hold strong implications for employee voicing. This can foster myriad positive outcomes such as employee engagement, job satisfaction, and knowledge sharing
$[34,26]$, but it can also present immediate challenges for management who are unprepared or ill equipped to respond meaningfully to such pervasive changes [33].

\section{Researching Voicing and ESNS}

Employers and researchers have begun to evaluate how ICTs can be leveraged to facilitate informal, prosocial employee voice and engagement. However, research on voice in ESNS, particularly to engender employee engagement, is still rare. ESNS support communication not only for sharing information, but also acts as a mechanism to amplify direct individual voice within an organization. It is critical to understand these mechanisms, as firms have already been experimenting directly and indirectly with promoting employee voice through ESNS with mixed results (for employers and for employees). In the framework outlined below we adopt an affordance perspective [34] for research specifically on ESNS and voicing.

\subsection{Proposed Voicing Framework}

While scholars have approached voicing behaviors based on a formal $v$. informal or a direct $v$. indirect continuum, we argue that voicing today occurs largely via informal, direct voicing mechanisms [57, 59, 72], where ICTs are increasingly important mediators of communication behaviors $[25,30,35,36,64]$. Direct, informal voicing behaviors may occur through organizationally sanctioned ICTs such as email and listservs, knowledge management systems, online suggestion systems, ESNS, and so on. These behaviors may lead to formal human resource actions by management, such as issuing policies on use of ICTs or sanctioning employees for their use of ICTs to express voice in ways that are not sanctioned (such as using ICTs to harass or create a hostile work environment). To focus research attention on the mechanisms and implications of informal, direct voicing mediated by ICTs generally, and focusing on ESNS in particular, we suggest two dimensions that highlight four categories of employee voicing: voicing context and voicing channel. (See Figure 1.) 


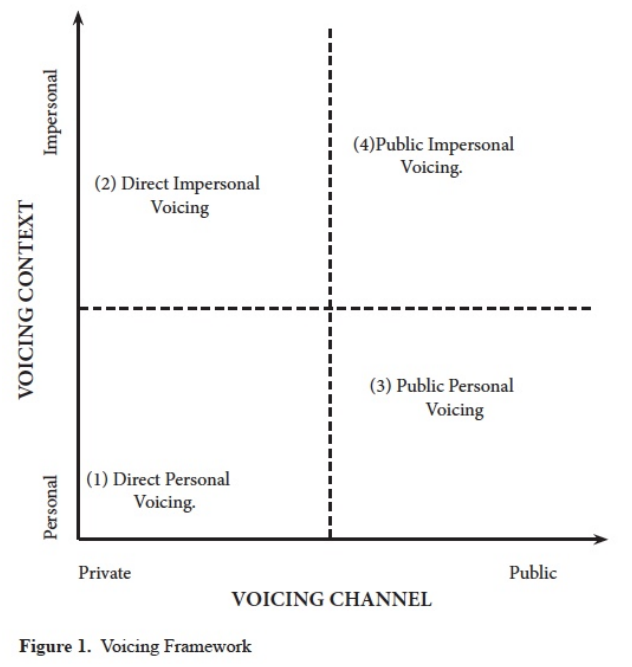

First, to seek change in an objectionable circumstance, employees may choose to express their voice personally or impersonally. Such decisions are often the result of their relationship with their line manager [11]. The context of the voicing behavior thus ranges from desired goals that are individual and personal, to impersonal and collective. For instance, an employee express that she deserves a raise (individual, personal) or that all employees are underpaid and deserve raises (collective, impersonal).

The second dimension, voicing channel, ranges from those that afford low visibility of, and heightened access control over the communication, to public channels in which communication is widely viewable and open to broad participation from others. A voicing channel is not synonymous with particular ICTs but represent affordances enacted through the use of ICT features to realize particular voicing effects. For instance, the employee may send an email requesting a raise directly to her supervisor (personal, private and controlled), use BCC (blind copy) to include an invisible audience (personal, controlled but less private), or copy the email to a large listserv (public, with broad viewing and possible participation, e.g., via listserv replies). Within ESNS features, this dimension suggests affordances for masspersonal communication [53], which are widely accessible but personalized, as well as metavoicing, by which employees may amplify an individual employee's voice significantly.

Normally employees would choose a voicing channel that would addresses their concern most directly. Thus, the employee would likely send her raise request directly to her supervisor (e.g. via email or one-to-one meeting), whereas she might argue for widespread wage increases publicly (e.g., through a listserv or at a public gathering) to garner others' support. The employee might shift the context as well as the channels for voicing. For instance, if a direct email about her own raise does not elicit the desired response from her supervisor, the aggrieved employee might shift her voice towards a general discontent about employee salaries utilizing the corporate ESNS.

This framework suggests four quadrants (See Figure 1). Direct personal voicing is the most private behavior for addressing individual problems or suggestions, expressed interpersonally and thus through ICT channels with limited visibility and more control by both the employee and employer. Often this private-personal context is where a grievance or suggestion is first explored one-to-one with a direct manager or HR representative. This is substantiated by a 2015 UK CIPD survey, which indicated that over one third of survey participants said that they would respond to conflict at work by discussing the issue with a manager or HR representative, and many emphasized the importance of resolving issues as 'close to the ground' as possible [11].

Impersonal direct voicing includes employee behaviors, in which a personal problem may be escalated up the organizational hierarchy and shift towards a more impersonal context in order to address a problematic situation through suggestions or grievances explored with various members of management and administration. These voicing behaviors may shift towards more formal voicing mechanisms within ICT channels that are private and controlled, such as suggesting workplace improvements or reporting harassment or ethical violations. These behaviors can be seen as a source of direct employee voice in which employees can raise general workplace concerns with their employers [2].

As employees explore organizational issues and their potential resolutions, behaviors may shift towards the personal, public voicing context, in which employees may express their voice so as to engage other employees and garner managerial attention to their own issues. In their representation-resolution gap study, Wibberley and Saundry [72] noted how employee respondents argued that engagement, the incidence of conflict, and management responses were intertwined. ESNS can be leveraged for their affordances of masspersonal communication, metavoicing, and high visibility so that each employee's voice has the possibility of being heard.

Finally, there is public, impersonal voicing where employers and employees engage in dialogue of an institutional nature, such as on the organization's strategy, or for resolving broader systemic issues between groups of employees and the organization. This type of inclusive dialogue and conflict resolution can also be evidenced by formal voicing mechanisms, such as collective bargaining and partnership 
arrangements (where they exist in organizations) [57]. Through voicing channels that allow broad visibility and participation, such as ESNS postings and comments, the organizational community can provide an audience and feedback on managerial initiatives. The ESNS affordances of wide reach and metavoicing could enhance employee engagement with the organization by allowing employees to expose issues and communicate more broadly and publicly.

The boundaries between the framework's quadrants, like the affordances of ICTs (and ESNS), are blurred in actual practices. ESNS features and typical use practices change, and thus an ESNS encompasses different affordances for both personalprivate and public-impersonal communication. While a normative and stepwise pattern between quadrants may be normatively plausible, it is possible for an employee's voicing behavior to move between any of the quadrants, whether intentionally or unintentionally.

\subsection{A Proposed Research Agenda}

While ICTs can be powerful mechanisms to leverage knowledge management, knowledge sharing, and employee voice, it is not surprising that the boundaries between the private use of ICTs for "voicing" easily (and often) may clash with organizational expectations for voicing behaviors that are allowable and productive. With the growing use of ESNS in organizations, we now build on the framework outlined above to highlight key topics associated with using ESNS for promotion of employee voice and engagement to guide future research.

How do employers and employees negotiate explicit and implicit rules for voice expression using ESNS?

With increasing use of ESNS within organizations, employers and employees are struggling to find the right balance between encouraging employees to use ESNS to contribute to organizational priorities and employees' self-interested, idiosyncratic voicing behaviors. Some firms do not host formal voice channels unless measurable cost efficiencies or other gains can be demonstrated [7, 45]. Yet, while such organizations have shied away from providing formal voice channels, they are much quicker to implement knowledge management and/or knowledge sharing ESNS, such as Lotus Notes, Yammer, Jive, Slack, or Beehive. Employees can readily appropriate these ESNS for direct voice to express opinions, or metavoice about others' opinions (public-personal).

As employees choose to interact on their own behalf in suggestion or grievance situations, through (formally sanctioned or informal) channels such as ESNS, how can management indicate allowable and acceptable use behaviors that are distinct from extraorganizational, personal uses of such systems? While policy manuals are a start, often times employees choose to operate outside the scope of policy, encouraged by the affordances of ICTs that allow for broader exposure and opportunities for collective voice. Thus, employers cannot avoid the challenge of negotiating with employees on how to express voice through various ICT channels in acceptable ways.

\section{Can personal use of social media be differentiated meaningfully from organization ESNS use?}

There is a grey area about where employees' personal free expression ends, and organizational precedent begins. This is evident in the term dubbed by the popular press as "Facebook Fired," a pejorative used to identify people who had been fired from their jobs for posts made on their personal social media accounts [52]. An example of this happened in 2013, when Justine Sacco, a PR executive was fired from New York based, InterActive Corp, before her plane even touched the ground in Africa after having Tweeted on a personal account, "Going to Africa. Hope I don't get AIDS. Just kidding. I'm white!" [14]. The Society of Human Resource Management cites examples of situations in which individuals were fired for social media offenses and gaffes related to personal expression, as well as the legal implications of those decisions [22]. In some cases, firings were found to be justified, in others employees fought back and won.

Such employment issues with social media use in private life complicate the prospects for engaging employees in prosocial voicing behaviors through ESNS platforms at work. Will employees be willing to take the risk of possible firing to express their views though organizationally sanctioned ESNS? Finding a balance of policies that protect the employer from possible litigation and bad publicity but does not suppress legitimate and beneficial voicing behaviors is not merely a question of "best practices," as advice and experience for dealing with these situations is just now developing [62] and may vary among organizations depending on organizational culture and mission.

\section{How do employers and employees negotiate responses to hijacked voice?}

Even in situations where employees adhere to internal channels such as ESNS, there is the potential for their voice to be 'hijacked,' or stripped out of its original context by someone other than the author, making an internal conversation public unbeknownst to the originator. For example, Google recently suffered a major PR problem when a memo posted by (former) employee James Damore, in which he asserted that 
women were biologically inferior for certain engineering positions [70], became public. While it was initially posted on an internal ESNS platform, the manifesto subsequently went viral internally before being leaked outside the organization, igniting a fury of media, HR, and legal backlash. Damore was fired, and subsequently filed a class action lawsuit against the company. This case highlights the problems employers and employees face when dealing with their voice being stripped from the personal dimension of intraorganizational discourse and thrust into the public domain unbeknownst to, or without the permission of the originator. The combination of ESNS and public social media platforms make such situations not only possible but also amplify their effect rapidly. Again, policy statements alone will not suffice to prevent such situations. Additional approaches, such as PR crisis management (internal and external), may be warranted.

\section{How do employers respond to metavoicing or masspersonal communication?}

Many scholars cite power imbalances as a predominant reason why employees may choose to circumvent the traditional practice of approaching a line manager at the first sign of conflict (personalprivate quadrant). Charlwood and Pollart [10] noted that the response of managers is critical in generating trust and developing channels of direct voice where conflict can be resolved. Power imbalances between managers and subordinates may discourage employees from taking this step $[4,7,10]$ when conflict in the workplace occurs between line managers and their employees [11].

Taking to social media is a convenient means of expressing voice in these situations, but these channels provide a much more personal and pubic communication channel than organizations have historically sanctioned for grievances or suggestions. Individuals utilizing social media often engage in masspersonal communication, where there is less distinction between dyadic and mass communication [53]. When employees begin sharing more personal information (even when work related) in a manner inconsistent with tacit organizational norms or values, employers must decide on a measured approach to encouraging open communication, while modeling an organizationally acceptable means of sharing. This is also true when employees choose to metavoice, e.g., by 'liking' or sharing the content of another. Metavoicing is an important tool for employees who can leverage the collective voice affordance, particularly in the absence of trade unions [43].

Employers must prepare to mitigate the disclosure of potentially sensitive information or respond to the amplifications afforded by ESNS when employees operate beyond corporate policy. Although employers reserve the right to delete harmful content, addressing it after the fact may be too late.

\section{Concluding Remarks}

In this paper we explore the intersection of employee engagement, employee voice, and ICTs (particularly ESNS) as channels for and enablers of employee voice. Many organizations are anxious to exploit the potential of ESNS to promote engagement and prosocial voice. However, encouraging employees to utilize ESNS also entails significant risks of human resource issues, public relations crises, and liability from inappropriate or uncontrolled uses. Simply writing policy manuals, or even eschewing ESNS will not suffice, as the public social media-private ESNS divide is permeable. Research is needed to support practitioners as they struggle with these issues. Such research can help to build theory on employee voice and engagement, regarding the significant and growing implications of ICTs on these behaviors, which have not yet been examined. Investigating ESNS-enabled voicing behaviors can also contribute to the organizational communication literature, as ICTs increasingly erode private-public boundaries and challenge institutionalized power and hierarchy in how and when organizational members communicate.

\section{References}

[1] M. Alavi and D. E. Leidner, "Review: Knowledge Management and Knowledge Management Systems: Conceptual Foundations and Research Issues," MIS Quarterly, vol. 25, no. 1, p. 107, 2001.

[2] R. Batt, A. J. S. Colvin, and J. Keefe, "Employee Voice, Human Resource Practices, and Quit Rates: Evidence from the Telecommunications Industry," ILR Review, vol. 55, no. 4, pp. 573-594, 2002.

[3] Barry, M. \& Wilkinson, A. "Pro-social or ProManagement? A critique of the conception of employee voice as a pro-social behavior within organizational behavior," British Journal of Industrial Relations, vol 54, no. 2, pp 261-284, 2016.

[4] Becerra-Fernandez, I, D. E. Leidner, and D. Leidner, Knowledge Management: An Evolutionary View. London, UNITED KINGDOM: Routledge, 2008.

[5] d. boyd. It's complicated: the social lives of networked teens. New Haven: Yale University Press, 2014.

[6] d. boyd and N. B. Ellison, "Social Network Sites: Definition, History, and Scholarship," Journal of ComputerMediated Communication, vol. 13, no. 1, pp. 210-230, 2007.

[7] A. Bryson, R. Gomez, and P. Willman, "Voice at work: What do employers want? A symposium summary," SocioEconomic Review, vol. 4, no. 2, pp. 279-282, 2006.

[8] E. R. Burris, J. R. Detert, and A. C. Romney, "Speaking Up vs. Being Heard: The Disagreement Around and 
Outcomes of Employee Voice," Organization Science, vol. 24, no. 1, pp. 22-38, 2013.

[9] C. T. Carr and R. A. Hayes, "Social Media: Defining, Developing, and Divining," Atlantic Journal of Communication, vol. 23, no. 1, pp. 46-65, 2015.

[10] A. Charlwood and A. Pollert, "Informal Employment Dispute Resolution among Low-Wage Non-Union Workers: Does Managerially Initiated Workplace Voice Enhance Equity and Efficiency?" British Journal of Industrial Relations, vol. 52, no. 2, pp. 359-386, 2014.

[11] CIPD, "Getting under the skin of workplace conflict: Tracing the experiences of employees." London: CIPD, 2015.

[12] R. Cross, P. Gray, A. Gerbasi, and D. Assimakopoulos, "Building engagement from the ground up: How top organizations leverage networks to drive employee engagement," Organizational Dynamics, vol. 41, no. 3, pp. 202-211, 2012.

[13] R. L. Daft and R. H. Lengel, "Organizational Information Requirements, Media Richness and Structural Design," Management Science, vol. 32, no. 5, pp. 554-571, 1986.

[14] F. deBoer, "Perspective | Corporations are cracking down on free speech inside the office - and out," Washington Post, 2017.

[15] J. M. DiMicco, W. Geyer, D. R. Millen, C. Dugan, and B. Brownholtz, "People Sensemaking and Relationship Building on an Enterprise Social Network Site," presented at the 42nd Hawaii International Conference on System Sciences, 2009, pp. 1-10.

[16] T. Dundon, A. Wilkinson, M. Marchington, and P. Ackers, "The meanings and purpose of employee voice," The International Journal of Human Resource Management, vol. 15, no. 6, pp. 1149-1170, 2004.

[17] N. B. Ellison, J. L. Gibbs, and M. S. Weber, "The Use of Enterprise Social Network Sites for Knowledge Sharing in Distributed Organizations: The Role of Organizational Affordances.," American Behavioral Scientist, vol. 59, no. 1, pp. 103-123, 2015.

[18] T. Erickson, “'Social' systems: designing digital systems that support social intelligence," AI \& Soc, vol. 23, no. 2, pp. 147-166, 2009.

[19] S. Faraj, S. Jarvenpaa, and A. Majchrzak, "Knowledge Collaboration in Online Communities," Organization Science, vol. 22, no. 5, pp. 1224-1239, 2011.

[20] J. W. Graham, Research in Organizational Behavior, vol. 8. Greenwhich, CT: JAI Press, 1986.

[21] M. Granovetter, "The Strength of Weak Ties," American Journal of Sociology, vol. 78, no. 6, pp. 1360-1380, 1973.

[22] K. Gurchiek, "Employers React to 'Troubling' Tweets, Social Media Posts by Employees," SHRM, 28-Nov-2017. Available: https://www.shrm.org/hr-today/news/hrnews/pages/employers-react-to-troubling-tweets-socialmedia-posts-by-employees.aspx. [Accessed: 14-May-2018]. [23] A. Hirschman, Exit, Voice, and Loyalty; responses to decline in firms, organizations, and states. Cambridge, Mass.: Harvard University Press, 1970.

[24] P. Holland, "Employers and Voice," in A. Wilkinson \& R.B. Freeman (Eds.) Handbook of Research on Employee Voice. Edward Elgar Publishing, 2014.
[25] P. Holland, B. K. Cooper, and R. Hecker, "Use of social media at work: a new form of employee voice?" The International Journal of Human Resource Management, vol. 27, no. 21, pp. 2621-2634, 2016.

[26] P. Holland, B. Cooper, and C. Sheehan, "Employee Voice, Supervisor Support, and Engagement: The Mediating Role of Trust," Human Resource Management, vol. 56, no. 6, pp. 915-929, 2017.

[27] J. Huang, J. Baptista, and S. Newell, "Communicational ambidexterity as a new capability to manage social media communication within organizations," The Journal of Strategic Information Systems, vol. 24, no. 2, pp. 49-64, 2015.

[28] S. Jarvenpaa and D. Leidner, "Communication and Trust in Global Virtual Teams," Organization Science, vol. 10, no. 6, 1999.

[29] W. A. Kahn, "Psychological conditions of personal engagement and disengagement at work.," Academy of Management Journal, vol. 33, no. 4, pp. 692-724, 1990.

[30] G. Kane, "The evolutionary implications of social media for organizational knowledge management," Information and Organization, vol. 27, no. 1, pp. 37-46, 2017.

[31] E. Karanges, A. Beatson, K. Johnston, and I. Lings, "Optimizing employee engagement with internal communication: A social exchange perspective," p. 26, 2014.

[32] J. Kim, J. MacDuffie, and F. Pil, "Employee voice and organizational performance: Team versus representative influence," Human Relations, vol. 63, no. 3, pp. 371-394, 2010.

[33] H. Lam, "Social media dilemmas in the employment context," Employee Relations, vol. 38, no. 3, pp. 420-437, 2016.

[34] P. M. Leonardi and E. Vaast, "Social media and their affordances for organizing: A review and agenda for research," The Academy of Management Annals, vol. 11, no. 1, pp. 150-188, 2017.

[35] P. M. Leonardi, "Social media, knowledge sharing, and innovation: Toward a theory of communication visibility," Information Systems Research, vol. 25, no. 4, pp. 796-816, 2014.

[36] P. M. Leonardi, "The social media revolution: Sharing and learning in the age of leaky knowledge," Information and Organization, vol. 27, no. 1, pp. 47-59, 2017.

[37] P. M. Leonardi, M. Huysman, and C. Steinfield, "Enterprise social media: definition, history, and prospects for the study of social technologies in organizations," Journal of Computer-Mediated Communication, vol. 19, no. 1, pp. 1-19, 2013.

[38] D. Lewin, Oxford Handbook of Conflict Management in Organizations, 1st ed. Oxford: Oxford University Press, 2014.

[39] C. Licoppe, “'Connected' presence: The emergence of a new repertoire for managing social relationships in a changing communication technoscape," Environment and Planning D: Society and Space, vol. 22, no. 1, pp. 135-156, 2004.

[40] C. Licoppe and Z. Smoreda, "Are social networks technologically embedded? How networks are changing today with changes in communication technology," Social Networks, vol. 27, no. 4, pp. 317-335, 2005. 
[41] K.-Y. Lin and H.-P. Lu, "Why people use social networking sites: An empirical study integrating network externalities and motivation theory," Computers in Human Behavior, vol. 27, no. 3, pp. 1152-1161, 2011.

[42] G. Lombardi, "Social Media Inside a Large Enterprise," in K. Ruck (Ed.), Exploring Internal Communication: Towards Informed Employee Voice, 3rd ed. Routledge Ltd, 2017.

[43] A. Majchrzak, S. Faraj, G. C. Kane, and B. Azad, "The contradictory influence of social media affordances on online communal knowledge sharing," Journal of Computer-Mediated Communication, vol. 19, no. 1, pp. 3855, 2013.

[44] A. Majchrzak, R. Rice, N. King, A. Malhorta, and S. $\mathrm{Ba}$, "Computer mediated interorganizational knowledge sharing: Insights from a virtual team innovating using a collaborative tool," Information Resources Management Journal, vol. 13, no. 1, pp. 44-53, 2000.

[45] P. Marginson, P. Edwards, T. Edwards, A. Ferner, and O. Tregaskis, "Employee representation and consultative voice in multinational companies operating in Britain," British Journal of Industrial Relations, vol. 48, no. 1, pp. 151-180, 2010.

[46] Maynes, T.D., \& Podsakoff, P.M., "Speaking more broadly: An examination of the nature, antecedents, and consequences of an expanded set of employee voice behaviors," Journal of Applied Psychology, vol. 99, no. 1, pp. 87-112, 2014.

[47] S. J. Miles and W. G. Mangold, "Employee voice: Untapped resource or social media time bomb?" Business Horizons, vol. 57, no. 3, pp. 401-411, 2014.

[48] P. Mowbray, A. Wilkinson, and H. Tse, "An integrative review of employee voice: Identifying a common conceptualization and research agenda," International Journal of Management Reviews, vol. 17, no. 3, pp. 382400, 2015.

[49] C. Mumford, "Finding a voice at work? New perspectives on employment relations," Personnel Review, vol. 45, no. 2, pp. 450-452, 2016.

[50] J. P. Near and M. P. Miceli, "Organizational dissidence: The case of whistle-blowing," Journal of Business Ethics, vol. 4, no. 1, pp. 1-16, 1985.

[51] P. O'Kane, O. Hargie, and D. Tourish, Key Issues in Organizational Communication. London; New York: Routledge, 2004.

[52] K. O'Connor and G. Schmidt, “'Facebook fired': Legal standards for social media-Based terminations of K-12 public school teachers," SAGE Open, vol. 5, no. 1, 2015.

[53] P. B. O'Sullivan and C. T. Carr, "Masspersonal communication: A model bridging the mass-interpersonal divide," New Media \& Society, vol. 20, no. 3, pp. 1161-1180, 2018.

[54] H. J. Oh, C. Lauckner, J. Boehmer, R. Fewins-Bliss, and K. Li, "Facebooking for health: An examination into the solicitation and effects of health-related social support on social networking sites," Computers in Human Behavior, vol. 29, no. 5, pp. 2072-2080, 2013.

[55] W. J. Orlikowski and J. D. Hofman, "An Improvisational Model for Change Management: The Case of Groupware Technologies," Sloan Management Review, p. 12, 1997.
[56] C. Rees, K. Alfes, and M. Gatenby, "Employee voice and engagement: connections and consequences," The International Journal of Human Resource Management, vol. 24, no. 14, pp. 2780-2798, 2013.

[57] W. Roche and P. Teague, "Do conflict management systems matter?" Human Resource Management, vol. 51, no. 2, pp. 231-258, 2012.

[58] K. Ruck and M. Welch, "Valuing internal communication; management and employee perspectives," Public Relations Review, vol. 38, no. 2, pp. 294-302, 2012.

[59] K. Ruck, M. Welch, and B. Menara, "Employee voice: An antecedent to organizational engagement?" Public Relations Review, vol. 43, no. 5, pp. 904-914, 2017.

[60] C. P. Ruppel and S. J. Harrington, "Sharing Knowledge Through Intranets: A Study of Organizational Culture and Intranet Implementation," IEEE Transactions on Professional Communication, vol. 44, no. 1, p. 17, 2001.

[61] P. Samuels, Gower Handbook of Internal Communication. Aldershot: Gower, 1997.

[62] G. Schmidt and K. O'Connor, "Fired for Facebook: Using NLRB guidance to craft appropriate social media policies," Business Horizons, vol. 58, no. 5, pp. 571-579, 2015.

[63] B. Sowa, Encyclopedia of Public Relations, 2nded 2013.

[64] L. Sproull and S. Kiesler, "Reducing social context cues: Electronic mail in organizational communication," Management Science, vol. 32, no. 11, pp. 1492-1512, 1986.

[65] A. T. Timur, D. Taras, and A. Ponak, "'Shopping for voice': Do pre-existing non-union representation plans matter when employees unionize?" British Journal of Industrial Relations, vol. 50, no. 2, pp. 214-238, 2012.

[66] J. W. Treem and P. M. Leonardi, "Social media use in organizations: Exploring the affordances of visibility, editability, persistence, and association," Annals of the International Communication Association, vol. 36, no. 1, pp. 143-189, 2013.

[67] B. van den Hooff and J. A. de Ridder, "Knowledge sharing in context: the influence of organizational commitment, communication climate and CMC use on knowledge sharing," Journal of Knowledge Management, vol. 8, no. 6, pp. 117-130, 2004.

[68] L. Van Dyne, J. W. Graham, and R. M. Dienesch, "Organizational citizenship behavior: Construct redefinition, measurement, and validation.," Academy of Management Journal, vol. 37, no. 4, pp. 765-802, 1994.

[69] L. Van Dyne and J. A. LePine, "Helping and voice extra-role behaviors: Evidence of construct and predictive validity.," Academy of Management Journal, vol. 41, no. 1, pp. 108-119, 1998.

[70] D. Wakabayashi, "Google fires engineer who wrote memo questioning women in tech" The New York Times, 2018.Available: https:/www.nytimes.com/2017/08/07/business/google-women-engineer-firedmemo.html [Accessed 14May-2018]

[71] B. Wehner, C. Ritter, and S. Leist, "Enterprise social networks: A literature review and research agenda," Computer Networks, vol. 114, pp. 125-142, 2017.

[72] G. Wibberley and R. Saundry, "From representation gap to resolution gap: Exploring the role of employee voice in conflict management," in Reframing Resolution, R. Saundry, P. Latreille, and I. Ashman, Eds. London: Palgrave Macmillan UK, 2016, pp. 127-148. 